\title{
Eliza Matusiak*
}

iD https://orcid.org/0000-0003-2455-0245

\section{Interaktywne słuchowisko Alicja 0700 jako dzieło po wielokroć otwarte Analiza i interpretacja}

\author{
Streszczenie
}

Sztuka audialna ewoluuje wraz ze zmianami technologicznymi. Słuchowisko staje się formą interaktywną z pogranicza gatunków. Audialny spektakl interaktywny wykorzystuje język właściwy tradycyjnej sztuce radiowej, który zostaje oparty o hipertekstualny system relacji danych. Pozwala to na stworzenie nie tylko nowego rodzaju dzieła fonicznego, ale także wielu nowych, wariantywnych dróg odsłuchu i interpretacji. Artykuł za swój cel obiera prezentację interaktywnego dzieła audialnego Alicja 0700, jego cech i wyróżników genologicznych w kontekście pojęcia „dzieła otwartego". Autorka za swą metodę badawczą wybrała analizę.

Słowa kluczowe: słuchowisko, sztuka audialna, hipertekst dzieło otwarte

Włoski semiolog Umberto Eco, w jednym ze swych najsłynniejszych tekstów - Dziele otwartym, zwrócił uwagę, iż współczesne dziedziny sztuki czynią próby uporządkowania, projektowania sposobów kształtowania „W związku z pewnymi sposobami opisywania rzeczywistości" ${ }^{\prime} \mathrm{w}$ perspektywie rozbitego pojęcia uporządkowanego kosmosu. Sztuka, akceptując ambiwalencję, poszukuje dlań

* Mgr, Uniwersytet Łódzki, Wydział Filologiczny, Katedra Dziennikarstwa i Komunikacji Społecznej, ul. Pomorska 171/173, 90-236 Łódź; e-mail: eliza.matusiak@filologia.uni.lodz.pl

1 U. Eco, Dzieło otwarte, przeł. L. Eustachiewicz i in., Wydawnictwo W.A.B., Wydanie III, Warszawa 2008, s. 33 
uzasadnienia ${ }^{2}$. Badacz wskazywał na ukazywanie przez sztukę „obrazów świata o wartości epistemologicznych metafor”3. Swą konstatację uzupełnił o sformułowanie, $i \dot{z}$ „[s]ą one nowym sposobem postrzegania, odczuwania, pojmowania i akceptowania wszechświata, w którym tradycyjny układ stosunków uległ zniszczeniu i w którym zarysowują się niejasno kontury nowego układu"4. Spostrzeżenia włoskiego filozofa zdają się znamienne wobec zmian, jakie stale zachodzą wśród artystycznych produkcji audialnych. Sztuka radiowa nieustannie i prężnie rozwija się w Teatrze Polskiego Radia oraz jego regionalnych rozgłośniach ${ }^{5}$. Dzieła owego teatru wyobraźni ${ }^{6}$ stanowić mogą swoistą egzemplifikację uporządkowanego kosmosu Eco. Są bowiem, zgodnie z zamysłem reżysera i autora scenariusza zaplanowane oraz zrealizowane od ekspozycji otwarcia, poprzez prezentacje postaci, zmiany dramaturgiczne wiodące do punktu kulminacyjnego aż po zamknięcie opowieści. Utwór audialny o skrystalizowanej dramaturgii i wyraźnie wyeksponowanym punctum ${ }^{7}$ jawi się przed słuchaczem jako spójna całość, otwarta na rozliczne interpretacje, jednak przywołująca określone konotacje za sprawą swych ładunków: semantycznego i emocjonalnego.

Inspiracją dla niniejszego tekstu jest słuchowisko interaktywne Alicja 0700, które stanowi przykład sui generis rozpadu uporządkowanego kosmosu audialnego teatru. Za sprawą konwergencji medialnej ${ }^{8}$ powstają dzieła audialne, które synkretycznie spajają tworzywo właściwe słuchowisku, czyli udźwiękowione słowo,

2 Por., tamże, s. 33-34.

3 Tamże.

4 Tamże.

5 Słuchowiska w polskim eterze w ujęciu holistycznym zbadała J. Bachura-Wojtasik. Zob. tejże, Odsłony wyobraźni. Współczesne słuchowiska radiowe, Wydawnictwo Adam Marszałek, Toruń 2012.

6 Autorem tegoż pojęcia jest Zdzisław Marynowski.

7 Semiolog Roland Barthes pojmowat istnienie punctum jako czynnika zmieniającego postrzeganie fotografii. „Ten szczegół - pisał Barthes - to [...] to, co mnie nakłuwa [...]”. Zob. Tegoż, Światło obrazu. Uwagi o fotografii, przeł. J. Trznadel, Wydawnictwo KR, Warszawa 1996, s. 47. Punctum sensu stricto odnosi się do przekazu wizualnego, jednak zasadne jest jego poszukiwanie także w produkcjach audialnych. Czyni to m.in. Joe Richman w swym tekście Diaries and Detritus: One Perfectionist's Search for Imperfection, https://sites.duke.edu/homelessness/ files/2010/o8/Diaries-Detritus.pdf [dostęp 5.09.2018]. Punctum w praktyce radiowej badała także K. Klimczak. Zob. tejże, Reportaże radiowe o krzywdzie i cierpieniu, Wydawnictwo Primum Verbum, Łódź 2011, s. 84-86.

8 Henry Jenkins definiuje konwergencję jako „przepływ treści pomiędzy różnymi platformami medialnymi, współpracę różnych przemysłów medialnych oraz migracyjne zachowania odbiorców mediów, którzy dotrą niemal wszędzie, poszukując takiej rozrywki, na jaką mają ochotę". Zob. tegoż, Kultura konwergencji. Zderzenie starych i nowych mediów, Wydawnictwa Akademickie i Profesjonalne, Warszawa 2007, s. 9. Zob. także: B. Bodzioch-Bryła, G. Pietruszewska-Kobiela , A. Regiewicz, Konwergencja nowych mediów i literatury, w: Literatura - nowe 
z hipertekstualnym przekierowaniem od jednej cząstki treściowej do innej. Celem tegoż artykułu jest zaprezentowanie i omówienie interaktywnego utworu audialnego oraz wskazanie dróg otwarcia dzieła na przykładzie słuchowiska Alicja 0700. Postaram się wykazać związki między hipertekstem a słuchowiskiem interaktywnym oraz ich komplementarność w wybranym tekście kultury w kontekście dzieła otwartego. Skupię się także na aktywności odbiorcy determinowanej przez hipertekstualność w odniesieniu do sztuki fonicznej. By wyznaczyć i sprecyzować cechy właściwe omawianemu hipertekstowi, w formułowaniu wniosków badawczych posłużę się analizą, czyli metodą charakterystyczną dla rozważań nad mediami. Analiza ma niejako charakter interdyscyplinarny, ponieważ sięga zarówno po wyznaczniki genologiczne słuchowiska, jak i teorię hipertekstu oraz pojęcie „dzieła otwartego". Motywowane jest to wspomnianą już, synkretyczną formą analizowanego spektaklu audialnego, która wymyka się wyznacznikom ontologicznym wyłącznie jednego gatunku.

Jednym z dzieł, które korzysta $\mathrm{z}$ cech dwu form medialnych: słuchowiska oraz hipertekstualnej organizacji danych jest interaktywne słuchowisko Alicja $0700^{10}$ według scenariusza Julii Szubert, Jarosława Wieły, Jakuba Mokrosińskiego i Wojciecha Wińskiego. Jak dostrzegła Magdalena Grenda, „Teatr Usta-Usta Republika w projekcie Alicja 0700 transformuje spektakl teatralny w interaktywne medium, które funkcjonuje w wirtualnej przestrzeni”"1. By podejmować próbę scharakteryzowania interaktywnego słuchowiska, na wstępie obligatoryjne staje się wyjaśnienie pojęcia hipertekstu. Mariusz Pisarski pojmuje hipertekst jako „nielinearną i niesekwencyjną organizację danych, tekst rozbity na poszczególne segmenty (leksje), po których czytelnik nawiguje według własnego uznania"'2 . Leksje są wobec siebie autonomiczne, każda $\mathrm{z}$ nich stanowi swego rodzaju akapit opowieści. Scalone zostają między sobą przy wykorzystaniu hiperłączy, które pełnią funkcję osobliwego środka transportu pomiędzy cząstkami utworu. Jak konstatował Jacek Zdzieborski:

media. Homo irretitus w kulturze literackiej XX i XXI wieku, red. A. Regiewicz, Wydawnictwo im. Stanisława Podobioskiego, Częstochowa 2014, s. 29-61.

9 Zob. M. Lisowska-Magdziarz, Metodologia badań nad mediami - nurty, kierunki, koncepcje, nowe wyzwania, „Studia Medioznawcze” 2013, nr 2, s. 27-42.

10 Słuchowisko dostępne jest pod adresem: http://alicja.sos.pl/momencik.html [dostęp 20.06.2019].

11 Magdalena Grenda w tekście poświęconym zwrotowi performatywnemu w teatrze przywołuje między innymi słuchowisko Alicja 0700. Zob. taż, Zwrot performatywny w poznańskim teatrze alternatywnym po roku 1989, http://www.tematyzszewskiej.pl/index.php/2016/02/24/zwrot-performatywny-w-poznanskim-teatrze-alternatywnym-po-roku-1989/, [dostęp 20.06.2019].

12 M. Pisarski, Hipertekst i hiperfikcja, w: Liternet.pl, red. P. Marecki, Wydawnictwo Rabid, Kraków 2003, s. 286. 
czytelnik hipertekstu staje się autorem własnego tekstu, na zasadzie podążania za odsyłaczami do innych leksji lub elementów audiowizualnych. Zdarza się, że bywa trudno, a czasem wręcz niemożliwe, odtworzyć raz przebytą ścieżkę lektury, przez co kolejną cechą hipertekstu godną podkreślenia jest jego nielinearność, a co z tym się wiąże, także lektura hipertekstu jest nielinearna, wielosekwencyjna, a nawet wielowymiarowa ${ }^{13}$.

Lektura czy też odsłuch, zależnie od różnorodności wykorzystanych mediów, prowadzą do konkretyzowania się dzieła, które, bez udziału odbiorcy, nie zaistnieje. „Hipertekst - pisał Roberto Simanowski - wydaje się przewodzić eksperymentom przełamania linearnej formy opowieści"14. Natomiast na język słuchowiska radiowego składają się między innymi słowo oraz jego wybrzmienie, gest foniczny, tło akustyczne, muzyka i cisza ${ }^{15}$. Słuchowisko o charakterze hipertekstualnym nie doczekało się badań i opisu w dyskursie akademickim, stąd też niemożliwe jest [jeszcze] przywołanie precyzyjnej definicji tegoż pojęcia. Niemniej, pojmowanie hipertekstu nie jako tekstu sensu stricto, a jako tekstu kultury, a więc jako formę wielomedialną, opartą o tekst, dźwięk i elementy wizualne, umożliwia postrzeganie Alicji 0700 jako audialnego hipertekstu, w którym leksje zastąpione zostają przez cząstki audialne, czyli kolejne sceny opowieści. Tym samym, opisanie wyróżników charakteryzujących dzieło Teatru Usta Usta Republika stanowić może preludium opracowania cech dystynktywnych słuchowiska interaktywnego, hipertekstualnego w ujęciu genologicznym. „Alicja 0700 - uzupełnia Magdalena Grenda - to pierwszy polski interaktywny spektakl-słuchowisko, w którym widz wpływa na rozwój akcji przez wciskanie przycisków na klawiaturze [wirtualnego] telefonu. Wybierając subiektywnie opcje, wpływa na przebieg [...] akcji”16. W tymże słuchowisku interaktywnym za sprawą bohaterki przeplatają się z sobą światy urojeń, rzeczywistości i bajek. Inspiracją do jego powstania była Tybetańska Księga Umarłych - „zbiór porad szeptanych do ucha osobie zmarłej, której dusza

13 J. Zdzieborski, Hipertekst - różnorodność rozumienia pojęcia, s. 17-18, https://bit.ly/2oLIOB4 [dostęp 5.09.2018].

14 R. Simanowski, Hipertekst. Znamiona, badania, poetyka, s. 375, http://pressto.amu.edu.pl/index.php/pt/article/view/11538/11217 [dostęp 5.09.2018].

15 Zob. m.in. J. Bachura-Wojtasik: Odsłony wyobraźni.., s. 30-40 oraz S. Bardijewska, Nagie słowo. Rzecz o słuchowisku, Dom Wydawniczy „Elipsa”, Warszawa 2001, s. 43; E. Godlewska-Byliniak, Słuchowisko, w: Od aforyzmu do zinu. Gatunki twórczości słownej, red. G. Godlewski, A. Karpowicz, M. Rakoczy, P. Rodak, Wydawnictwo Uniwersytetu Warszawskiego, Warszawa 2014, s. 451-461, a także E. Pleszkun-Olejniczakowa, Muzy rzadko się do radia przyznaja. Szkice o słuchowiskach i reportażach radiowych, Wydawnictwo Primum Verbum, Łódź 2012, s. 11-30.

16 M. Grenda, dz. cyt., http://www.tematyzszewskiej.pl/index.php/2016/02/24/zwrot-performatywny-w-poznanskim-teatrze-alternatywnym-po-roku-1989/, [dostęp 20.06.2019]. 
wędruje w zaświatach, narażona na moment ponownych narodzin"17. Bohaterowie słuchowiska to tytułowa Alicja, jej brat oraz Doktor. Odbiorca, korzystając z przeglądarki internetowej, przełącza się między kolejnymi scenami opowieści, wysłuchując konsekwencji swych wyborów. Historia traktuje o losach tytułowej Alicji, której życie owiane jest tajemnicą. Dziewczyna targana silnymi emocjami skłonna jest wyjawić prawdę. Słuchacz dzwoni do bohaterki poprzez wirtualny telefon wyświetlony na ekranie komputera. Alicja pyta wówczas, czy chcemy, by tym razem opowiedziała nam prawdziwą historię. Słuchowisko łamie tzw. „,czwartą ścianę", ponieważ zwraca się do słuchacza wprost i czyni go nie tylko interpretatorem dzieła, ale i swym uczestnikiem, odpowiedzialnym niejako za zdarzenia, które nastąpiły w życiu dziewczyny. Słuchacz, do którego bohaterowie Alicji 0700 zwracają się bezpośrednio, komunikuje się z dziełem - poprzez kolejne decyzje warunkuje przebieg historii, a konsekwencje tychże wyborów stanowią sprzężenie zwrotne determinujące obustronną komunikację.

W toku analizy słuchowiska interaktywnego wyłania się fundamentalna wartość pojęcia dzieła otwartego opracowanego przez Umberta Eco. Umożliwia ono szereg rozważań nad wariantywnością interpretacyjnych perspektyw audialnego hipertekstu. Dzieło przemawia do odbiorcy nie tylko przez samą treść, ale i formę. Zarówno struktura fonicznej opowieści, jak i sensy, jakie przekazuje, są wobec siebie komplementarne i koherentne. Formalne zabiegi czerpiące z nielinearnych narracji i hipertekstualnych rozwiązań prowadzą do zwielokrotnienia treści. Wielość treści rozszerza możliwości interpretacyjne odbiorcy. „[...]Sztuka współczesna - konstatował włoski semiolog - liczy na Nieład: nieład, który wszakże nie jest ślepy i nieuleczalny i nie oznacza klęski wszelkich prób uporządkowania, ale jest nieładem płodnym, pozytywnym[...]"18. Wykorzystanie nielinearnego sposobu prowadzenia narracji w słuchowisku Alicja 0700 wprowadza nieład, który staje się płodny w możliwe zakończenia i interpretacje opowieści. Nieład potęgowany jest także poprzez nieustanne zwodzenie odbiorcy. Fabuła tegoż interaktywnego tekstu kultury nie przebiega linearnie według zaplanowanego rozwoju akcji. Za sprawą interaktywnego otwarcia dzieła odbiorca zostaje zderzony z cyrkularnym modelem historii. Wybierając kolejne ścieżki odsłuchu, krąży wokół, skądinąd zwodniczego, leitmotiv 19 $^{19}$ tajemnicy, którą skrywa tytułowa bohaterka. Słuchowisko, korzystając ze swych środków genologicznych, przy zastosowaniu hipertekstualnej, a więc nielinearnej formy, implikuje interaktywne doświadczenie odbiorcze.

17 http://www.alicja.sos.pl/, [dostęp 20.06.2019].

18 U. Eco, dz. cyt., s. 33.

19 Na istotną obecność leitmotivu w sztuce radiowej zwracały uwagę m.in. J. Bachura-Wojtasik oraz A. Pawlik. Zob. tychże, Znaczeniowa funkcja muzyki w słuchowisku, w: „Acta Universitatis Lodziensis. Folia Litteraria Polonica" 2012, nr 3, s. 165, https://bit.ly/2oLIOB4 [dostęp 20.06.2019]. 
Słuchacz zostaje wprowadzony w świat Alicji przez interakcję z postaciami Brata i Doktora. Prowokowany jest przez nich do odkrywania prawdy o tytułowej dziewczynie. Im więcej decyzji podejmuje, tym sytuacja staje się mniej klarowna, a prawda zdaje się nie istnieć.

Eco konkludował, że „każda forma dająca się percypować, o ile ma wartość este-

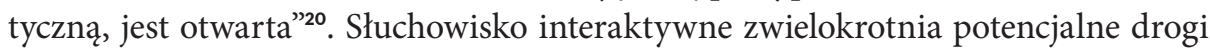
otwarcia dzieła poprzez wykorzystanie wielości ścieżek, którymi może podążać odbiorca przechodząc między kolejnymi etapami historii. Każda z wysłuchanych składowych staje się swoistym mikrosłuchowiskiem, opowieścią do percypowania oraz interpretowania. Łączenie składowych na wielorakie sposoby przywołuje nowe konteksty. Zmianie ulega zatem sens dzieła, a historia staje się po wielokroć otwarta. Audialny hipertekst, zgodnie z tezą Eco, jest dziełem otwartym. Interpretator odkrywa nowe powiązania między cząstkami interaktywnego słuchowiska. Odnajduje alternatywne drogi do opowiedzenia historii bohatera. Ma wpływ na kształt, jaki przyjmie zakończenie opowieści. Sieć możliwych powiązań między kolejnymi cząstkami hipertekstualnego spektaklu poszerza spektrum potencjalnych perspektyw odbiorczych. Tym samym słuchacz staje się nie tylko odbiorcą, ale i uczestnikiem owych wydarzeń. Zyskuje szansę na immersyjne uczestnictwo w dziele, przyczynienie się do otwarcia tegoż. Korzystając z obranej przez twórców formy dzieła, słuchacz łączy niejako rolę zarówno odbiorcy, jak i twórcy. Mariusz Filiciak dostrzegł, że „hipertekst to bardziej czasownik niż rzeczownik: gotowy produkt działalności autora zostaje zastąpiony przez proces tworzenia sensu w wyniku działań odbiorcy w ramach uprzednio przygotowanej struktury" ${ }^{21}$. Użytkownik porusza się w polu zdarzeń, nazwanym przez norweskiego teoretyka Espena Aarsetha event space ${ }^{22}$ hipertekstu. Brak obecności i aktywności odbiorcy oznacza, iż dzieło nie zaistnieje. To decyzje słuchacza konkretyzują słuchowisko, wyznaczają konkretną ścieżkę odsłuchu, toteż staje się on niejako autorem danego wykonania.

Umberto Eco nadmienił, iż sztuka jest swego rodzaju „poszukiwaniem modeli »otwartych«, zdolnych zapewnić zmiany i przygodę" ${ }^{\text {23 }}$. W słuchowisku Alicja 0700 zmiany toczą się nieustannie. Słuchacz jest zwodzony, permanentnie balansuje na pograniczu prawdy i zmyślenia, faktów i iluzji. Przyjmuje wielorakie perspektywy: w części scen znajduje się niejako z boku zdarzeń świata przedstawionego, w wybranym ich wyimku otrzymuje wskazówki od Doktora, w innych od brata Alicji, jeszcze w odmiennych - od niej samej. W dominującej części jest jednak uczestni-

20

21 M. Filiciak, Druk kontra piksele. Hipertekst w literaturze, w: Liternet. Literatura i internet, red. P. Marecki, Wydawnictwo Rabid, Kraków 2002, s. 122.

22 M. Pisarski, Ergodyczność..., http://techsty.art.pl/hipertekst/teoria/ergodyzm.htm [dostęp 20.06.2019].

23 U. Eco, dz. cyt., s. 35. 
kiem zdarzeń. Decyduje na przykład, co stanie się z Alicją po wypadku lub też, czy w ogóle wypadkowi ulegnie. Ujawnienie prawdy okazuje się niemożliwe, ponieważ nie jest to celem słuchowiska - bazuje ono na swego rodzaju aporii. Percypowanie dzieła, odsłuch kolejnych mikrosłuchowisk stanowi drogę do odkrywania kolejnych mikroświatów, które nie czynią swą podstawą logicznych przyczynowo-skutkowych zależności. Badaczka nowych mediów, Katarzyna Prajzner, odnotowała, iż

fakt, że interaktywny tekst ma status całości, ale też, dla swego czytelnika jawi się jako fragment, powoduje,[...] że "poszukuje on całości, nawet jeśli nie ma żadnego dowodu na to, że owe fragmenty stanowiły kiedykolwiek całość. Ten rodzaj impasu jest [...] główną figurą stylistyczną mechanizmu funkcjonowania interaktywnego tekstu. To aporia w najdosłowniejszym z sensów « ${ }^{24}$.

W słuchowisku Alicja 0700 aporia przejawia się dwojako - w warstwie verbum, ponieważ świat przedstawiony nie jest logicznie spójną opowieścią, a ponadto, zgodnie ze spostrzeżeniem Prajzner - aporia występuje w strukturze dzieła, bowiem słuchacz nie ma w momencie percypowania opowieści dostępu do jej holistycznego wymiaru. Brak też pewności, czy w jakiejkolwiek z konfiguracji odsłuchu mikrosłuchowiska stanowią całość, czy też w każdej ze ścieżek są swoistym amalgamatem niepowiązanych ze sobą wyimków. Tego rodzaju rozwiązanie dramaturgiczno-strukturalne wzmacnia otwarcie dzieła, zachęca do interaktywnych poszukiwań, interakcji z bohaterami, odkrywania kolejnych informacji o ich charakterologicznych wyróżnikach i wątkach fabularnych.

Umberto Eco w swych esejach pisał, iż

[...] każde dzieło sztuki, ukończone i zamknięte niby doskonale zbudowany organizm, jest równocześnie dziełem otwartym, poddającym się stu różnym interpretacjom, zresztą nienaruszającym jego niepowtarzalnej istoty. Każda percepcja dzieła jest więc zarazem interpretacją i wykonaniem, gdyż w trakcie każdej z nich dzieło odżywa na nowo w oryginalnej perspektywie ${ }^{25}$.

W odniesieniu do tekstu kultury zbudowanego na podstawie hipertekstualnego systemu organizacji cząstek każdorazowe wykonanie dzieła jest kluczowe dla jego zaistnienia. Zatem nie tylko liczba potencjalnych interpretacji pozostaje otwarta, bowiem zależna jest od indywidualnej perspektywy każdego odbiorcy. Także samo wykonanie dzieła wynika z samodzielnej, jednostkowej ścieżki odsłuchu, która przy każdorazowym obcowaniu ze słuchowiskiem może ulegać zmianie. Włoski filozof

24 K. Prajzner, Tekst jako świat i gra. Modele narracyjności w kulturze współczesnej, Wydawnictwo Uniwersytetu Łódzkiego, Łódź 2009, s. 116.

25 U. Eco, dz. cyt., s. 70. 
akcentował, iż w poszukiwaniach w sztuce „sprowadzamy [...] formę do systemu relacji po to, ażeby wydobyć to, co ogólne i zamienne w owym systemie relacji, ażeby wykazać, że każdy przedmiot ma pewną »strukturę«, która go łączy z innymi przedmiotami"26. W słuchowisku Alicja 0700, a więc w dziele hipertesktualnym, bardziej niż o strukturze można mówić o systemie relacji. Owo spostrzeżenie jest jednak zasadne, ponieważ relacje spajające cząstki interaktywnego słuchowiska pozwalają na odnajdywanie nowych przedmiotów interpretacji, stwarzanie nowych kontekstów. W jednej ze scen słuchacz decyduje, czy Alicja zostanie zabrana do domu, czy też zostanie z Doktorem, który miałby rzekomo chcieć skrzywdzić dziewczynę. Jeśli odbiorca zechce pomóc Alicji, którą w tejże scenie postrzegać można jako nieco nieporadną, zdaną na empatię innych, to trafia z bohaterką do domu. Nie spotyka go jednak wdzięczność, a Alicja ma do niego szereg pretensji, wskazując na naiwność słuchacza. Co więcej, Doktor ma gościć w domu postaci, a zadaniem odbiorcy jest przygotowanie kolacji dla niego i Alicji. Wystarczy zatem jeden wybór, jedna interaktywna obecność słuchacza w świecie przedstawionym, by kontekst został w pełni przemodelowany. Decyzje, które słuchacz-użytkownik podejmuje $\mathrm{w}$ ramach dostępnego mu świata przedstawionego stanowią czynnik immanentny dla każdorazowego wybrzmienia opowieści. System, na jakim bazuje dzieło, stanowi determinantę jej fabularnego przebiegu. Wybory odbiorcy warunkują zarówno zmiany w fabularnej przestrzeni dzieła, jak i jego zaistnienie jako takie. Należy jednak nadmienić, iż słuchowisko interaktywne nie jest dziełem nieskończenie otwartym. Odbiorca porusza się w przestrzeni opowieści, która, choć otwarta na wariantywne odsłuchy, nie jest nieskończona. Spektakl Alicja 0700 pozwala na przekształcenia w ramach uprzednio wykreowanego przez twórców systemu relacji i powiązań.

Ryszard Kluszczyński analizując problematykę dzieła interaktywnego zwracał uwagę, iż „twórca projektuje sytuację, w której publiczność je [dzieło] wykona”27. Warto uzupełnić ową tezę o kolejną konstatację badacza, w której akcentował, iż rolą artysty nie jest stworzenie artefaktu, a „dyspozytywu: układu-kontekstu, w którym odbiorca/interaktor konstruuje przedmiot swego doświadczenia i jego sens" ${ }^{\text {"28 }}$. Alicja 0700 jest zatem interaktywnym słuchowiskiem, dyspozytywem zbudowanym w hipertekstualnym systemie, który umożliwia przechodzenie między swymi audialnymi cząstkami poprzez hiperłącza. Każde z mikrosłuchowisk podlega interpretacjom, podobnie jak każdorazowa ścieżka odsłuchu stanowi

26 Tamże, s. 55.

27 R. Kluszczyński, Dramaturgia interaktywna. W poszukiwaniu nowego formatu widowiska audiowizualnego, https://www.youtube.com/watch?v=ydISUs7rCzc [dostęp 5.09.2018].

28 R. Kluszczyński, Teoretyczno-kulturowe i filozoficzne konteksty sztuki interaktywnej, w: Interaktywne media sztuki, red. A. Porczak, Wydawnictwo Akademii Sztuk Pięknych im. Jana Matejki, Kraków 2009, s. 34 . 
swoiste, podatne na interpretacje, wykonanie dzieła. Tym samym Alicja 0700 jest dziełem otwartym po wielokroć.

Umberto Eco podkreślał, iż pojęcie dzieła otwartego nie jest pojęciem aksjologicznym, a eseje autora „nie pretendują [...] do przeprowadzenia podziału na dzieła wartościowe (»otwarte«) i pozbawione wartości, anachroniczne, niedobre (»zamknięte«)"29. W mojej opinii, otwartość audialnych form hipertekstualnych także nie powinna być rozpatrywana w kategoriach aksjologicznych. Badacze Jon Dovey oraz Helen W. Kennedy w swej książce Kultura gier komputerowych podkreślali rolę interaktywności w zwiększaniu zasobu potencjalnych interpretacji.

[C]yfrowe i technologiczne formy interaktywności - konstatują Dovey i Kennedy - nie umniejszają znaczenia wielokrotnych praktyk aktywnych interpretacji zachodzących w wypadku tradycyjnych mediów, ale tak naprawdę dzięki nim są one o wiele liczniejsze i bardziej złożone. Jeśli czytelnik/widz/użytkownik/gracz ma dostęp do większej liczby wyborów oferowanych przez tekst, to zwiększa się zakres możliwych interpretacji ${ }^{30}$.

Dzieła synkretyczne o interaktywnym charakterze mogą przyczynić się do dotarcia do nowego, przyzwyczajonego do internetowych praktyk odbiorczych grona słuchaczy. Słuchowiska interaktywne winno rozpatrywać się jako szansę dla rozwoju sztuki słuchowiskowej w perspektywie jej współistnienia z nowymi mediami. Audialny spektakl Alicja 0700 to egzemplifikacja wykorzystania rozwiązań technologicznych w procesie twórczym. Słuchowisko nie jest już wyłącznie opowieścią, która traktuje o losach wybranych bohaterów. Staje się dziełem, w którym możemy uczestniczyć, które mówi niejako o słuchaczu, do słuchacza i przez słuchacza. Sztuka audialna otwiera się zatem zarówno na nowe interpretacje, jak i doświadczenia odbiorcze.

\section{Bibliografia}

Bachura Joanna, Odsłony wyobraźni. Współczesne słuchowiska radiowe, Wydawnictwo Adam Marszałek, Torun 2012.

Bachura Joanna, Pawlik Aleksandra, Znaczeniowa funkcja muzyki w słuchowisku, „Acta Universitatis Lodziensis. Folia Litteraria Polonica” 2012, nr 3, s. 162-170.

Bardijewska Sława, Nagie słowo. Rzecz o słuchowisku, Dom Wydawniczy Elipsa, Warszawa 2001.

29 U. Eco, dz. cyt., s. 51.

30 J. Dovey, H.W. Kennedy, Kultura gier komputerowych, przeł. T. Macios, A. Oksiuta, Wydawnictwo Uniwersytetu Jagiellońskiego, Kraków 2011, s. 8. 
Barthes Roland, Światto obrazu. Uwagi o fotografii, przeł. Jacek Trznadel, Wydawnictwo KR, Warszawa 1996.

Bodzioch-Bryła Bogusława, Pietruszewska-Kobiela Grażyna, Regiewicz Adam, Konwergencja nowych mediów i literatury, w: Literatura - nowe media. Homo irretitus w kulturze literackiej XX i XXI wieku, red. Adam Regiewicz, Wydawnictwo im. Stanisława Podobioskiego, Częstochowa 2014, s. 29-61.

Dovey Jon, Kennedy Helen W., Kultura gier komputerowych, przeł. Tomasz Macios, Anna Oksiuta, Wydawnictwo Uniwersytetu Jagiellońskiego, Kraków 2011.

Eco Umberto, Dzieło otwarte, przeł. Lesław Eustachiewicz i in., Wydawnictwo W.A.B., Wydanie III, Warszawa 2008.

Filiciak Mirosław, Druk kontra piksele. Hipertekst w literaturze, w: Liternet. Literatura i internet, red. Piotr Marecki, Wydawnictwo Rabid, Kraków 2002, s. 119-126.

Godlewska-Byliniak Ewelina, Stuchowisko, w: Od aforyzmu do zinu. Gatunki twórczości słownej, red. Grzegorz Godlewski, Marta Rakoczy, Paweł Rodak, Wydawnictwo Uniwersytetu Warszawskiego, Warszawa 2014, s. 451-461.

Grenda Magdalena, Zwrot performatywny w poznańskim teatrze alternatywnym po roku 1989, http://www.tematyzszewskiej.pl/index.php/2016/02/24/zwrot-performatywny-w-poznanskim-teatrze-alternatywnym-po-roku-1989/, [dostęp 20.06.2019].

Jenkins Henry, Kultura konwergencji. Zderzenie starych i nowych mediów, Wydawnictwa Akademickie i Profesjonalne, Warszawa 2007.

Klimczak Kinga, Reportaże radiowe o krzywdzie i cierpieniu, Wydawnictwo Primum Verbum, Łódź 2011.

Kluszczyński Ryszard, Dramaturgia interaktywna. W poszukiwaniu nowego formatu widowiska audiowizualnego, https://www.youtube.com/watch?v=ydISUs7rCzc [dostęp 5.09.2018].

Kluszczyński Ryszard, Teoretyczno-kulturowe i filozoficzne konteksty sztuki interaktywnej, w: Interaktywne media sztuki, red. Antoni Porczak, Wydawnictwo Akademii Sztuk Pięknych im. Jana Matejki, Kraków 2009, s. 7-54.

Lisowska-Magdziarz Małgorzata, Metodologia badań nad mediami - nurty, kierunki, koncepcje, nowe wyzwania, „Studia Medioznawcze” 2013, nr 2, s. 27-42.

Pisarski Mariusz, Ergodyczność..., http://techsty.art.pl/hipertekst/teoria/ergodyzm. htm [dostęp 20.06.2019].

Pisarski Mariusz, Hipertekst i hiperfikcja, w: Liternet.pl, red. Piotr Marecki, Wydawnictwo Rabid, Kraków 2003, s. 285-291.

Pleszkun-Olejniczakowa Elżbieta, Muzy rzadko się do radia przyznają. Szkice o stuchowiskach i reportazach radiowych, Wydawnictwo Primum Verbum, Łódź 2012.

Prajzner Katarzyna, Tekst jako świat i gra. Modele narracyjności w kulturze wspótczesnej, Wydawnictwo Uniwersytetu Łódzkiego, Łódź 2009.

Richman Joe, Diaries and Detritus: One Perfectionist's Search for Imperfection, https://sites.duke.edu/homelessness/files/2010/08/Diaries-Detritus.pdf [dostęp 5.09.2018]. 
Simanowski Roberto, Hipertekst. Znamiona, badania, poetyka, http://pressto.amu. edu.pl/index.php/pt/article/view/11538/11217 [dostęp 5.09.2018].

Zdzieborski Jacek, Hipertekst - różnorodność rozumienia pojęcia, https://bit. ly/2oLIOB4 [dostęp 5.09.2018].

\title{
Interactive radio drama Alicja 0700 as the multiple open work. Analysis and interpretation
}

\author{
Summary
}

Radio art evolves due to technological changes. Radio drama is becoming an interactive piece of artwork which exists on the borderland of genres. An interactive audio play uses characteristic features of the classical radio art and unites them with the hypertextual structure. Due to these modifications, there emerges not only a new type of audio play, but also a lot of alternative ways of listening and interpretation. The aim of the article is to present interactive radio drama Alicja 0700, its genre's determinants in reference to the idea of "the open work".

Keywords: radio drama, radio art, hypertext, the open work

Eliza Matusiak - doktorantka w Katedrze Dziennikarstwa i Komunikacji Społecznej Uniwersytetu Łódzkiego. W centrum jej badawczych zainteresowań znajduje się sztuka audialna - jej dokumentalna, ale przede wszystkim fikcjonalna strona. Obecnie opracowuje rozprawę doktorską poświęconą interaktywnym słuchowiskom o ergodycznym charakterze. Jest współautorką monografii Brzmienie Holocaustu. O reprezentacjach Zagłady w sztuce radiowej. 